\title{
APLIKASI PERMASALAHAN TRANSPORTASI BBM JENIS PREMIUM MENGGUNAKAN FUZZY DI PT.GEOTAMA ENERGI
}

\author{
Paryati, Yudiyanta, Awang Hendrianto \\ Jurusan Teknik Informatika Universitas Pembangunan Nasional“Veteran"Yogyakarta \\ Jl. Babarsari 2, Tambakbayan, Yogyakarta 55281 Telp/Fax. (0274) 485323 \\ e-mail : : yaya_upn_cute@yahoo.com
}

\begin{abstract}
The design and implementation of a software used as a tool aid to crease a transportation model which is equipped with a fuzzy cost parameter by using genetic algorithm. Waterfall methodology, which comprised of analyzing, designing, implementing and testing processes, was used in the software engneering. One way to deal with uncertainty in making such decision is by using fuzzy principles. The software is applied in the programming language environment of Borland Delphi. The solution transportation problem can be solved by heuristic approach using genetic algorithm. The analysis of programme value shows that the process on evaluation case straight proportional with the result of the multiplication of the source of depot total and the destination depot corelation coefisien 0.89. The analysis shows that the amount of population is straight linear to each of the case evaluation towards the process time with correlation coefisien 0.99 .
\end{abstract}

Keywords : Genetic Algorithm, Fuzzy.

\section{Abstrak}

Telah dilakukan perancangan dan implementasi suatu perangkat lunak untuk menyelesaikan permasalahan transportasi dengan parameter biaya fuzzy, menggunakan algoritma genetika. Perancangan perangkat lunak menggunakan metodologi Waterfall, yang terdiri dari analisa, desain, implementasi serta pengujian. Suatu cara untuk menangani ketidakpastian dalam pengambilan keputusan pada sistem transportasi tersebut menggunakan prinsip fuzzy. Perangkat lunak diimplementasikan di lingkungan bahasa pemrograman Borland Delphi. Penyelesaian masalah transportasi dapat diselesaikan dengan pendekatan secara heuristik menggunakan algoritma genetika. Analisa hasil program menunjukkan bahwa waktu proses pada kasus uji berbanding lurus dengan hasil kali jumlah depot sumber dan depot tujuan dengan koefisien korelasi 0.89 . Analisa juga menunjukkan bahwa banyaknya populasi adalah berbanding lurus atau linier untuk masing-masing kasus uji terhadap waktu proses dengan koefisien korelasi 0.99 .

Kata kunci : Algoritma Genetika, Fuzzy.

\section{PENDAHULUAN \\ Latar Belakang}

Permasalahan transportasi BBM jenis premium di PT.Geotama Energi membahas pengiriman komoditas barang dari beberapa sumber ke sejumlah tujuan. Masing masing sumber dan tujuan mempunyai persediaan dan permintaan kebutuhan komoditas dalam jumlah tertentu. Tujuan penyelesaian masalah ini adalah mengalokasikan persediaan masing-masing sumber untuk memenuhi permintaan masing-masing tujuan sedemikian sehingga dapat meminimasi biaya

\section{Transportasi secara total.}

Algoritma genetika dapat digunakan untuk menyelesaikan masalah trasportasi linear . Penggunaan algoritma genetika ini merupakan contoh constrains optimization problem yang meneliti mengenai bagaimana batasan-batasan tersebut dengan algoritma genetika dan menunjukkan kemampuan algoritma genetika yang memberikan kebebasan untuk menggunakan sembarang struktur data pada suatu permasalahan secara bersama-sama dengan operator genetikanya. 
"Masalah transportasi linear kriteria ganda dan masalah transportasi solid serta planar kriteria ganda dapat diselesaikan menggunakan algoritma genetika (Barnhart \& Laporte 2007). Beberapa metode pemrograman linear multi objective khususnya untuk masalah transportasi telah dikembangkan dengan berbagai cara pendekatan yang konvensional, untuk kasus multi objective adalah untuk menghasilkan titik ekstrim non dominasi pada ruang keputusan. Dengan mengikuti metodologi ini penggunaan algoritma genetika dimaksudkan untuk menentukan himpunan titik non dominasi, dengan ide dasar ini algoritma genetika merupakan cara yang dapat digunakan untuk menyelesaikan masalah optimasi yang multi objective (Branke et al, 2008). Dengan pendekatankriteria ganda, disamping biaya transportasi banyak faktor lain yang berpengaruh seperti waktu pengiriman kuantitas barang yang dikirimkan dan penurunan produksi.

Alasan dilakukannya penelitian ini karena pada sistem transportasi, pengaruh kemacetan sarana transportasi menghasilkan ketidakpastian pada sebagian atau seluruh koefisien pada fungsi objektif, seperti biaya transportasi atau waktu pengiriman yang menjadi tidak dapat diketahui secara pasti. "Suatu cara untuk menangani ketidakpastian dalam pengambilan keputusan tersebut menggunakan prinsip fuzzy. Dengan prinsip fuzzy, akan dikembangkan suatu metode penyelesaian masalah transportasi dengan tambahan berupa biaya transportasi yang bersifat fuzzy untuk menangani ketidakpastian pada parameter fungsi objektif.

\section{Perumusan Masalah}

Adapun perumusan masalahnya adalah Bagaimana merancang dan mengimplementasikan perangkat lunak untuk menyelesaikan masalah transportasi BBM jenis premium menggunakan fuzzy di PT. Geotama Energi.

\section{Batasan Masalah}

Permasalahan yang akan dibahas dalam penelitian ini dibatasi pada :

a. Kondisi Balanced, jumlah komoditas persediaan barang pada depot sumber sama dengan jumlah komoditas permintaan pada depot tujuan.

b. Parameter biaya transportasi fuzzy menggunakan bilangan triangular fuzzy number (triangular fuzzy number) dengan $a_{1} \leq a_{2} \leq a_{3}$.

c. Masalah transportasi yang dibahas adalah planar, dengan kendaraan pengangkut serba sama serta kapasitas tidak dibatasi.

d. Biaya transportasi pengiriman barang dari sumber ke tujuan berbanding lurus (linear) dengan banyaknya unit barang yang dikirimkan.

\section{Kajian Literatur}

Algoritma Genetika (GA) merupakan cabang dari algoritma evolusi yang merupakan metode adaptive yang biasa digunakan untuk memecahkan suatu pencarian nilai dalam sebuah optimasi (Sivanandam \& Deepa, 2007).

\section{Struktur umum GA adalah sebagai berikut :}

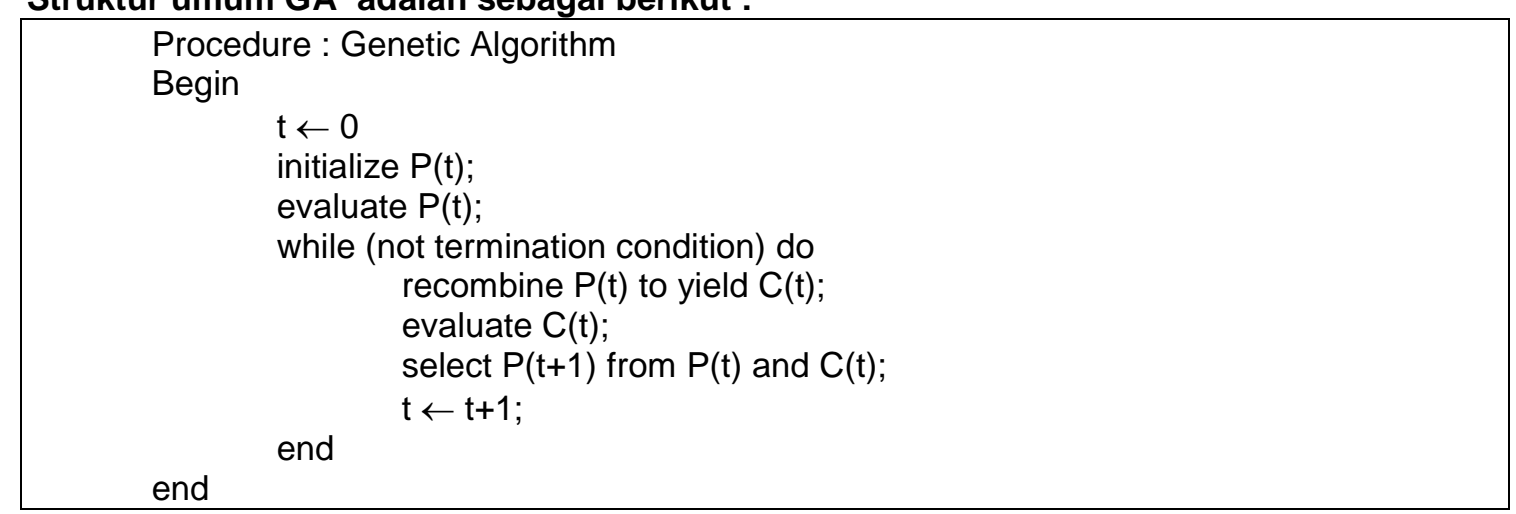




\section{Representasi Data Fuzzy}

Aspek ketidakpastian banyak dipelajari didalam usaha pengembangan model sistem yang lebih mendekati dunia nyata. Dan semua bentuk ketidakpastian dianggap unscientific, maka di dalam pandangan modern, ketidakpastian dipertimbangkan sebagai sesuatu yang esensial yang tidak perlu dihindari, karena lebih merepresentasikan dunia nyata. Setiap model harus memperhatikan tiga karakteristik dasar sebagai tolok ukur pendekatan terhadap dunia nyata, yaitu tingkat kerumitan tingkat kehandalan, dan ketidakpastian. Ketidakpastian memiliki peran penting dalam memaksimalkan kegunaan dari sebuah model system (Timothy, 2004).

\section{Himpunan Fuzzy}

Teori himpunan fuzzy untuk merepresentasikan bentuk ketidak pastian yang bersifat samar (Agusnaba, 2009). Fungsi keanggotaan diwakili oleh nilai bilangan yang terletak pada interval $[0,1]$, dengan nilai ekstrim 0 dan 1 berturut-turut menunjukkan denial dan affirmation terhadap keanggotaannya.

\section{Masalah Transportasi}

Masalah transportasi dapat dibagi menurut fungsi tujuan serta batasannya (Cascetta, 2009). Secara matematis masalah transportasi ini dapat diformulasikan sebagai berikut :

$$
\begin{aligned}
& \text { Minimasi } z_{q}=\sum_{i=1}^{m} \sum_{j=1}^{n} \tilde{c}_{i j}^{q} x_{i j} \quad \mathrm{q}=1,2 \\
& \text { Kendala } \quad \sum_{j=1}^{n} x_{i j}=a_{i,}, \quad i=1,2, \ldots, m \\
& \sum_{i=1}^{m} x_{i j}=b_{j,}, \quad j=1,2, \ldots, n \\
& \sum_{i=1}^{m} a_{i}=\sum_{j=1}^{n} b_{j} \\
& x_{i j} \geq 0 \quad \forall i, j \\
& \begin{array}{ll}
a_{i}>0 & \forall i
\end{array} \\
& b_{j}>0 \quad \forall j \\
& \tilde{c}_{i j}^{q} \geq 0 \quad \forall i, j, q
\end{aligned}
$$

Dengan:

$x_{i j} \quad=$ jumlah unit yang dikirimkan dari sumber $i$ ke tujuan $j$

$\tilde{c}_{i j}^{q} \quad=$ biaya pengiriman 1 unit dari dari sumber $i$ ke tujuan $j$

$a_{i} \quad=$ banyaknya persediaan pada sumber $i$

bj = banyaknya permintaan pada tujuan $j$

\section{Siklus kerja system engineering menggunakan model waterfall.}

Tahap-tahap siklus kerja system engineering (Pressman, 2007) adalah sebagai berikut :

1. System Engineering. Tahap ini dimulai dengan menetapkan semua hal yang diperlukan dalam pelaksanaan proyek.

2. Analisis. Tahap dimana system engineering menganalisis kebutuhan proyek, pembuatan dan pengembangan perangkat lunak.

3. Desain.Tahap ini merupakan penerjemahan dari keperluan atau data yang telah dianalisis ke dalam bentuk yang mudah dimengerti user.

4. Kode. Tahap berikutnya adalah menerjemahkan data atau pemecahan masalah yang telah dirancang ke dalam bahasa pemrograman komputer yang telah ditentukan.

5. Testing. Setelah program selesai dibuat maka tahap berikutnya adalah uji coba sistem. 


\section{METODE PENELITIAN}

\section{Analisa kebutuhan dan perancangan}

Cara Merangking Bilangan Fuzzy dengan Nilai Integral

Masalah transportasi fuzzy multikriteria yang solid dan planar dapat diselesaikan menggunakan algoritma genetika. Implementasi dasarnya menyerupai penyelesaian pada masalah transportasi multikriteria, namun yang membedakan adalah penanganan kekaburannya. Dalam optimasi multikriteria (Ehrgott, 2005), pareto optimal digunakan dalam menentukan nilai optimal. Jika koefisien tujuan ditunjukkan dengan angka fuzzy, nilai tujuan menjadi angka fuzzy. Karena angka fuzzy menunjukkan banyak kemungkinan angka riil, maka sulit untuk menentukan solusi pareto diantara banyak kemungkinan solusi. Teknik merangking fuzzy dapat membantu membandingkan angka fuzzy untuk menentukan nilai optimal. Solusi Pareto ditentukan dengan mendasarkan pada nilai tujuan fuzzy yang diurutkan.

Metode ranking angka fuzzy dengan nilai integral dapat digunakan untuk membandingkan angka fuzzy. Secara umum, fungsi keanggotaan dapat dibagi menjadi bagian kiri dan bagian kanan. Untuk masalah minimisasi nilai integral dari fungsi invers bagian kiri merefleksikan sudut pandang yang optimistik, dan nilai integral dari fungsi inversi bagian kanan merefleksikan sudut pandang yang pesimistik dari pengambil keputusan. Kombinasi konvek nilai integral bagian kiri dan kanan melalui indeks optimisme, disebut nilai integral total, yang digunakan untuk mengurutkan angka fuzzy.

Algoritma genetika pada permasalahan transportasi (Tetsuya \& Xin, 2006) adalah sebagai berikut :

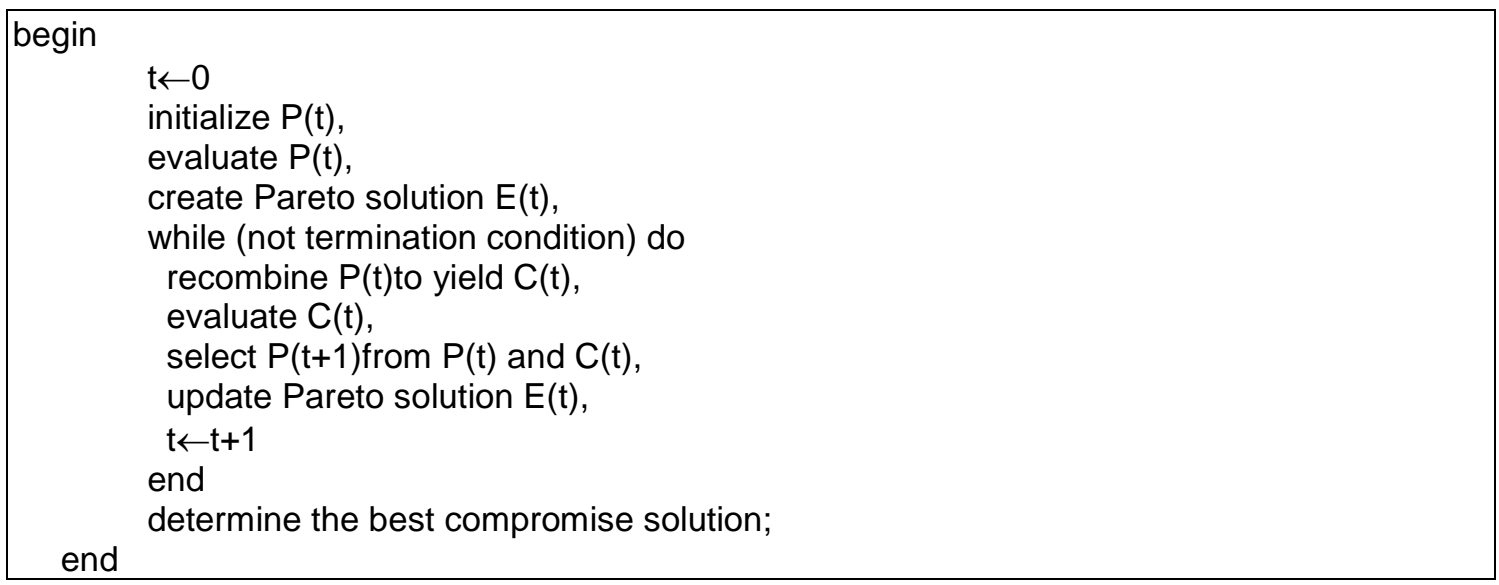

\section{Perancangan Arsitektur TraFAG}

Perancangan Arsitektur TraFAG dapat disajikan pada gambar 1 di bawah ini : 


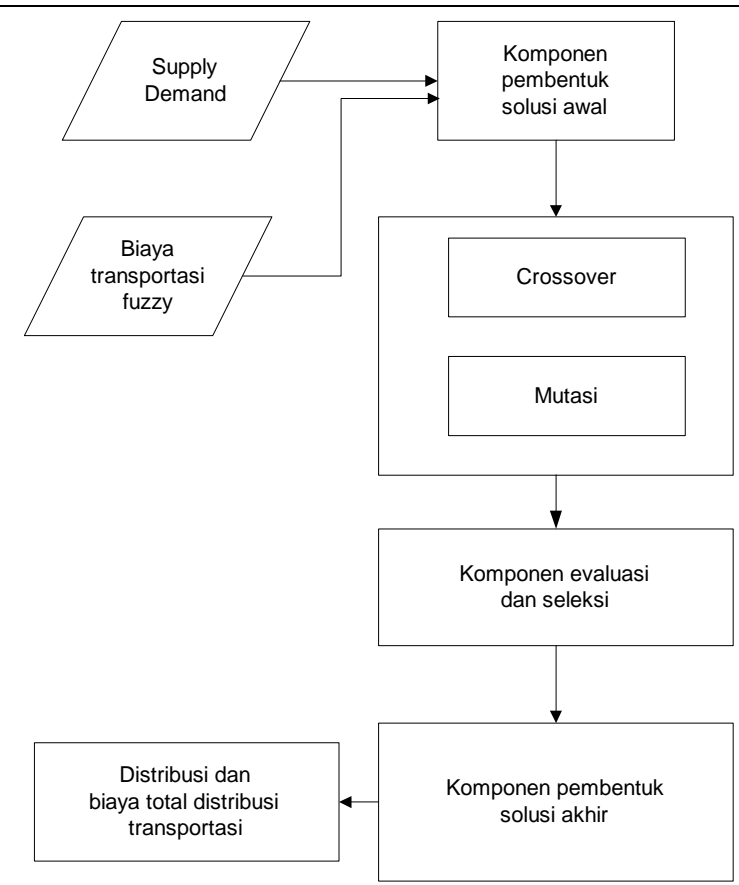

Gambar 1. Perancangan Arsitektur TraFAG

\section{Perancangan Model Fungsional}

Model Fungsional menggambarkan proses-proses yang terjadi dalam perangkat lunak berupa masukan serta keluaran sistem yang terjadi pada semua proses. Model fungsional TraFAG akan digambarkan dengan diagram aliran data.

\section{Diagram Aliran Data}

Diagram aliran data untuk TraFAG terdiri dari konteks diagram, yang menggambarkan sistem TraFAG dan masukan yang datang serta keluaran dari sistem dan diagram aliran data level 1 dan 2 yang merupakan turunan dari konteks diagram dengan proses yang lebih terperinci.

\section{Diagram Aliran Data level 0}

DFD level 0 Diagram konteks untuk TraFAG disajikan pada gambar 2 di bawah ini. Masukan ke sistem adalah parameter, biaya transportasi fuzzy (cost), permintaan (demand) dan persediaan (supply). Keluarannya berupa solusi distibusi transportasi dan biaya transportasi fuzzy.

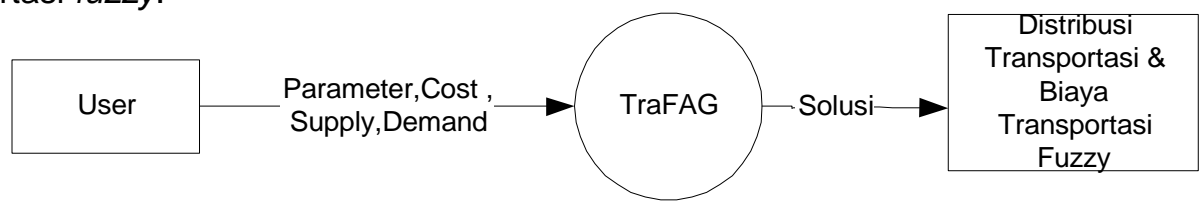

\section{Gambar 2. DFD Level 0 Diagram Konteks.}

\section{Diagram Aliran Data level 1}

Dari diagram konteks, diagram aliran data dipartisi menjadi diagram aliran data level 1 yang disajikan pada gambar 3 di bawah ini. Diagram aliran data level 1 terdiri dari 7 proses utama, yaitu :

1. Proses baca data (proses 1). Proses ini membaca data supply, demand dan biaya transportasi (cost) fuzzy yang direpresentasikan dalam bentuk TFN (Triangular Fuzzy Number).

2. Proses inisialisasi (proses 2). Proses ini membentuk populasi di awal generasi dari data supply dan demand yang tersedia.

3. Proses rekombinasi (proses 3). Pada proses ini dilakukan operasi-operasi genetika yang berupa krossover dan mutasi untuk meghasilkan offspring. 
4. Proses evaluasi (proses 4). Proses ini melakukan evaluasi perhitungan fungsi fitness dari kromosom-kromosom hasil inisialisasi dan hasil rekombinasi. Karena terdapat dua kriteria transportasi maka perhitungan fungsi objektif juga melibatkan dua kriteria transportasi tersebut.

5. Proses seleksi (proses 5). Pada proses ini dilakukan pemilihan offspring hasil rekombinasi berdasarkan nilai fitness yang dihitung pada saat proses evaluasi. Kromosom yang mempunyai nilai fitness yang baik akan muncul pada generasi berikutnya.

6. Proses pareto (proses 6). Proses ini memilih kromosom-kromosom yang terbaik pada setiap generasi.

7. Proses topsis (proses 7). Proses ini mencari penyelesaian kompromi terbaik diantara solusi pareto.

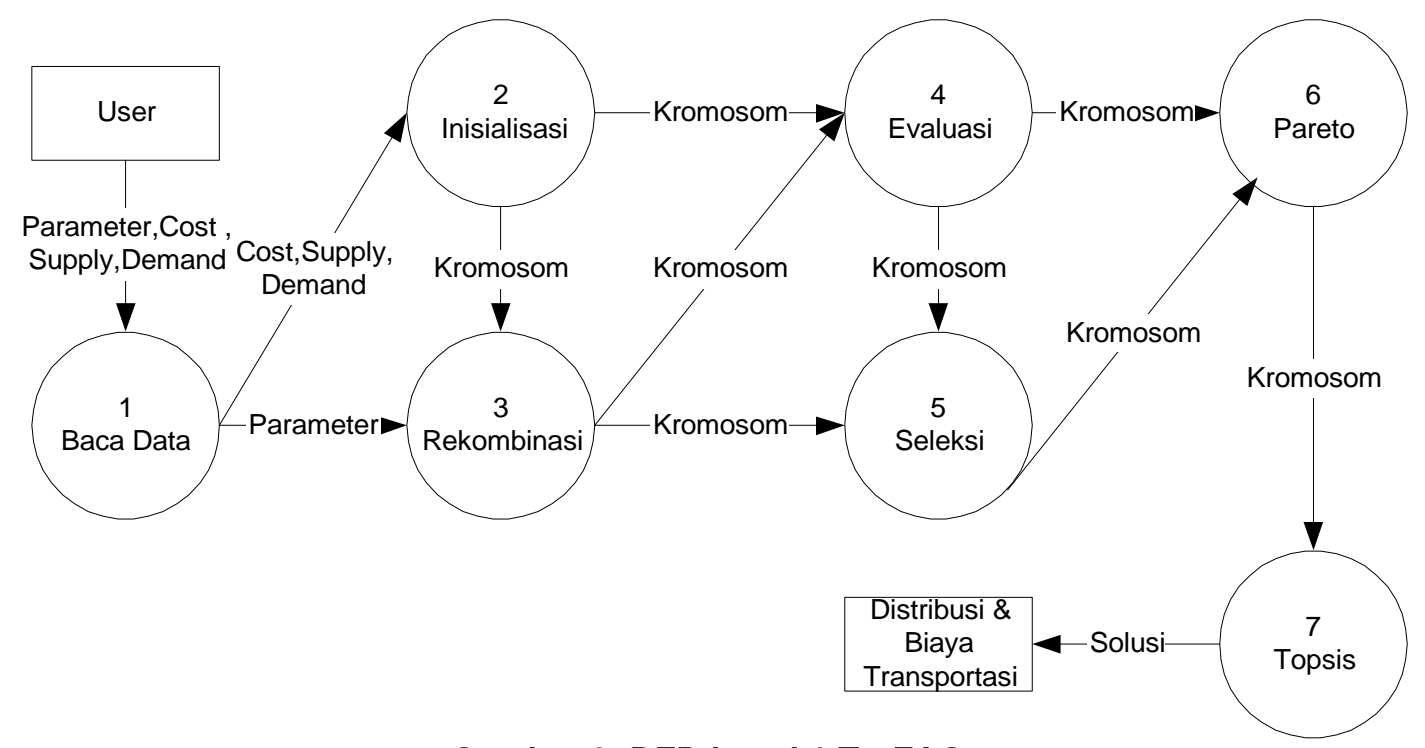

Gambar 3. DFD Level 1 TraFAG

\section{Kamus Data}

Kamus data memuat definisi dari semua data dengan diagram aliran data. Tabel $1 \mathrm{di}$ bawah ini memuat kamus data yang digunakan dalam diagram aliran data untuk TraFAG.

Tabel 1. Kamus data

\begin{tabular}{|l|l|l|}
\hline \multicolumn{1}{|c|}{ DATA } & \multicolumn{1}{|c|}{ DESKRIPSI } & \multicolumn{1}{c|}{ TIPE } \\
\hline Cost & $\begin{array}{l}\text { Biaya transportasi pada kriteria 1 } \\
\text { dan kriteria 2 }\end{array}$ & \{integer\} \\
\hline Demand & Permintaan pada depot tujuan & \{integer\} \\
\hline Kromosom & $\begin{array}{l}\text { Nilai kromosom individu pada } \\
\text { suatu populasi }\end{array}$ & \{integer \\
\hline Parameter & $\begin{array}{l}\text { Parameter fuzzy, parameter } \\
\text { Transportasi, parameter genetika }\end{array}$ & (integer,real) \\
\hline Solusi & Hasil berupa solusi transportasi & \{integer\} \\
\hline Supply & Persediaan pada depot sumber & \{integer) \\
\hline
\end{tabular}

\section{Perancangan Struktur Modul}

Struktur program dibentuk dengan melakukan pemfaktoran. Hasil pemfaktoran dan asosiasinya dengan proses dalam diagram aliran data disajikan pada tabel 2 . 
Tabel 2. Hasil pemfaktoran

\begin{tabular}{|l|l|}
\hline \multicolumn{1}{|c|}{ PEMFAKTORAN } & \multicolumn{1}{|c|}{$\begin{array}{c}\text { ASOSIASI DENGAN } \\
\text { DAD }\end{array}$} \\
\hline 1. Baca Data & Proses 1 \\
\hline 1.1 Edit Data & Proses 1.1 \\
\hline 1.2 Setting Parameter & Proses 1.2 \\
\hline 1.3. Cek Kondisi Balance & Proses 1.3 \\
\hline 2. Inisialisasi & Proses 2 \\
\hline 3. Rekombinasi & Proses 3 \\
\hline 3.1 Pemilihan kromosom crossover & Proses 3.1 \\
\hline 3.2 Pemilihan kromosom mutasi & Proses 3.2 \\
\hline 3.3 Crossover & Proses 3.3 \\
\hline 3.4 Mutasi & Proses 3.4 \\
\hline 3.4.1 Buat Submatriks & Proses 3.4.1 \\
\hline 3.4.2 Realokasi & Proses 3.4.2 \\
\hline 3.4.3 Replace & Proses 3.4.3 \\
\hline 4. Evaluasi & Proses 4 \\
\hline 4.1 Evaluasi kriteria 1 & Proses 4.1 \\
\hline 4.2 Evaluasi kriteria 2 & Proses 4.2 \\
\hline 5. Seleksi & Proses 5 \\
\hline 5.1 Hitung fungsi Fitness & Proses 5.1 \\
\hline 5.2 Sorting fitness & Proses 5.2 \\
\hline 5.3 Merging kromosom & Proses 5.3 \\
\hline
\end{tabular}

Terdapat 6 buah struktur data yang dimiliki Trafag, yaitu

1. Struktur data untuk bilangan fuzzy segitiga (Triangular Fuzzy Number).

2. Struktur data untuk kromosom

3. Struktur data untuk depot sumber dan tujuan

4. Struktur data untuk matriks transportasi fuzzy.

5. Struktur data untuk individu

6. Struktur data untuk populasi

\section{Perancangan Antarmuka}

Antarmuka pada TraFAG dirancang untuk mempermudah pemakaian perangkat lunak. TraFAG dilengkapi dengan struktur menu dan layar saji.

\section{Perancangan Struktur Menu}

TraFAG menyediakan menu sebagai sarana untuk mempermudah pengguna melakukan perintah-perintahnya. Perintah pada menu dapat ditampilkan dengan mengklik menu tersebut, sehingga didapat menu pulldown. Ada 4 menu untuk TraFAG, yaitu :

1. Menu Berkas, terdiri dari 3 menu, yaitu

a. Ambil, untuk mengambil dan membaca file data input transportasi.

b. Simpan, untuk menyimpan data input transportasi pada memory ke sebuah file.

c. Keluar, untuk keluar dari program TraFAG.

2. Menu Sunting, terdiri dari 5 menu, yaitu

a. Parameter GA : untuk menyunting parameter GA.

b. Parameter transportasi : untuk menyunting banyaknya depot sumber dan tujuan.

c. Parameter Fuzzy: untuk menyunting alpha $(\alpha)$.

d. Kriteria Transportasi1 : untuk menyunting suppy dan demand pada masing-masing depot serta biaya transportasi pada kriteria pertama.

e. Kriteria Transportasi2 : untuk menyunting suppy dan demand pada masing-masing depot serta biaya transportasi pada kriteria kedua.

3. Menu Eksekusi, terdiri dari 2 menu, yaitu

a. Eksekusi, untuk menjalankan program dan menampilkan hasil eksekusi program.

b. Parameter eksekusi, untuk menyunting parameter yang berhubungan dengan eksekusi program. 
4. Menu Bantuan, terdiri dari 2 menu, yaitu

a. Cara penggunaan, berisi cara penggunaan program TraFAG.

b. Perihal, untuk menampilkan informasi mengenai program TraFAG. di bawah ini.

Bentuk struktur menu untuk perangkat lunak TraFAG disajikan pada gambar 4 seperti

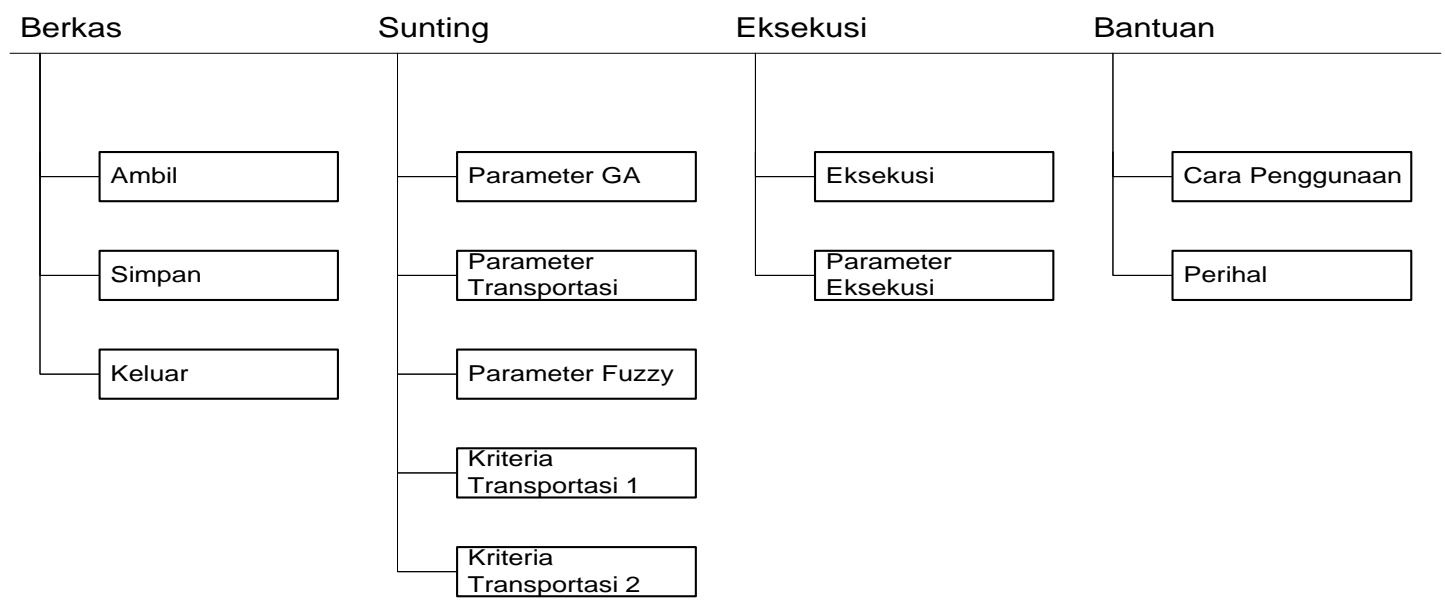

Gambar 4. Perancangan Antarmuka TraFAG

Hasil keluaran TraFAG tampil dengan adanya perintah eksekusi. Keluaran dari TraFAG berupa hasil transportasi terbaik, fungsi objektif, nilai integral populasi dan waktu proses. Implementasi

Penyiapan antarmuka TraFAG dibentuk oleh beberapa file unit dan beberapa file form untuk membentuk antarmuka dengan pemakai yang disajikan pada tabel 3 dibawah ini.

Tabel 3. File unit dan file form

\begin{tabular}{|l|l|l|}
\hline \multicolumn{1}{|c|}{ File Form } & \multicolumn{1}{|c|}{ File Unit } & \multicolumn{1}{c|}{ Diskripsi kegunaan } \\
\hline UlnputTFN.dfm & UInputTFN.pas & Menyunting input berupa bilangan fuzzy segitiga. \\
\hline UInputUnit.dfm & UlnputUnit.pas & Memberi masukan unit komoditas pada suatu depot \\
\hline UKriteria1.dfm & UKriteria1.pas & $\begin{array}{l}\text { Menyunting kriteria transportasi pertama serta } \\
\text { persediaan dan permintaan depot }\end{array}$ \\
\hline UKriteria2.dfm & UKriteria2.pas & $\begin{array}{l}\text { Menyunting kriteria transportasi kedua serta } \\
\text { persediaan dan permintaan depot }\end{array}$ \\
\hline UParamek.dfm & UParamek.pas & Menyunting parameter eksekusi \\
\hline UParamFuzzy.dfm & $\begin{array}{l}\text { UParamFuzzy.pa } \\
\text { s }\end{array}$ & Menyunting parameter Fuzzy (alpha) \\
\hline UParamGA.dfm & UParamGA.pas & Menyunting parameter algoritma genetika \\
\hline UParamTrans.dfm & $\begin{array}{l}\text { UParamTrans.pa } \\
\text { s }\end{array}$ & Menentukan jumlah depot sumber dan tujuan \\
\hline UPerihal.dfm & UPerihal.pas & Menampilkan perihal program \\
\hline
\end{tabular}

\section{File-file Program}

Selain file-file yang dimiliki form, TraFAG juga didukung file-file bantu lain yang tidak didukung form. Pada umumnya file bantu tanpa form yang tertera pada tabel 4 di bawah ini digunakan untuk eksekusi program. File-file pendukung TraFAG disajikan pada tabel 4 di bawah ini :

\begin{tabular}{|l|l|}
\hline Unit & Tabel 4. File bantu \\
\hline UFileMng.pas & Unit untuk menyimpan dan mengambil data di file \\
\hline UGenetika.pas & Unit untuk melakukan operasi operasi genetika \\
\hline UGlobal.pas & Unit yang berisi tipe dan variabel global, serta inisialisasi nilai variabel. \\
\hline
\end{tabular}




\section{Implementasi Program berdasarkan hasil pemfaktoran} bawah ini :

Hasil pemfaktoran dalam implementasi program disajikan pada tabel 5 yang terletak di

Tabel 5. Implementasi program berdasarkan hasil pemfaktoran

\begin{tabular}{|c|l|l|}
\hline \multicolumn{1}{|c|}{ PEMFAKTORAN } & \multicolumn{1}{|c|}{ MODUL } & \multicolumn{1}{c|}{ PROSEDUR } \\
\hline 1. Baca Data & UTraFAG.pas & Ambil1Click \\
\hline 1.1 Edit Data & UKriteria1.pas, & StringGrid1DblClick \\
\hline UKriteria2.pas & UTraFAG.pas & $\begin{array}{l}\text { ParameterGA1Click, } \\
\text { ParameterFuzzy1Click } \\
\text { ParameterTransportasi1Click }\end{array}$ \\
\hline 1.3. Cek Kondisi Balance & UGenetika.pas & UjiSupplyDemand \\
\hline 2. Inisialisasi & UGenetika.pas & InitialisasiPopulasi \\
\hline 3. Rekombinasi & UGenetika.pas & Rekombinasi \\
\hline 3.1 Pemilihan kromosom crossover & UGenetika.pas & Pilih kromosom krosover \\
\hline 3.2 Pemilihan kromosom mutasi & UGenetika.pas & Pilih kromosom mutasi \\
\hline 3.3 Crossover & UGenetika.pas & Crossover \\
\hline 3.4 Mutasi & UGenetika.pas & Mutasi \\
\hline 3.4.1 Buat Submatriks & UGenetika.pas & BuatSubMatrik \\
\hline 3.4.2 Realokasi & UGenetika.pas & Realokasi \\
\hline 3.4.3 Replace & UGenetika.pas & Replace \\
\hline 4. Evaluasi & UGenetika.pas & Evaluate \\
\hline 4.1 Evaluasi kriteria 1 & UGenetika.pas & Eval1 \\
\hline 4.2 Evaluasi kriteria 2 & UGenetika.pas & Eval2 \\
\hline 5. Seleksi & UGenetika.pas & Select \\
\hline 5.1 Hitung fungsi Fitness & UGenetika.pas & Hitungfitness \\
\hline 5.2 Sorting fitness & USorting.pas & Sortingfitness \\
\hline 5.3 Merging kromosom & USorting.pas & Merging \\
\hline 6 Pareto & UGenetika.pas & SolusiPareto \\
\hline 7. Topsis & UGenetika.pas & Topsis \\
\hline
\end{tabular}

\section{HASIL DAN PEMBAHASAN}

Bab ini menjelaskan besarnya memori yang diperlukan untuk program TraFAG dan hasil analisa dari pengujian yang telah dilakukan terhadap program TraFAG. Pengujian sebanyak 15 buah kasus uji yaitu kasus uji 2 sampai dengan kasus uji 15. Masing masing kasus menyatakan jumlah depot sumber dan depot tujuan. Pengujian yang dilakukan adalah pengaruh jumlah depot, jumlah populasi, jumlah generasi terhadap waktu proses. Pengaruh parameter alpha terhadap nilai integral. Pengaruh jumlah generasi, jumlah populasi, parameter alpha, probabilitas crossover, probabilitas mutasi terhadap fungsi fitness.

\section{Kebutuhan Memori} berikut :

Memori yang diperlukan untuk membuat program TraFAG dapat dirangkum sebagai

- Source Compiled

- Code Size

- Data Size

- Initial Stack Size

- File Size

$$
\begin{aligned}
& : 1476 \text { lines } \\
& : 328244 \text { byte } \\
& : 1179005 \text { byte } \\
& : 16384 \text { byte } \\
& : 403365 \text { byte }
\end{aligned}
$$

\section{Pengaruh jumlah depot terhadap waktu proses.}

Berdasarkan hasil penelitian dan pembahasan pada masing-masing kasus uji merefleksikan ordo matriks, maka waktu proses pada kasus uji akan berbanding lurus atau linier dengan hasil kali jumlah depot sumber dan depot tujuan dengan koefisien korelasi 0.89 yang disajikan dalam gamber 5 di bawah ini : 


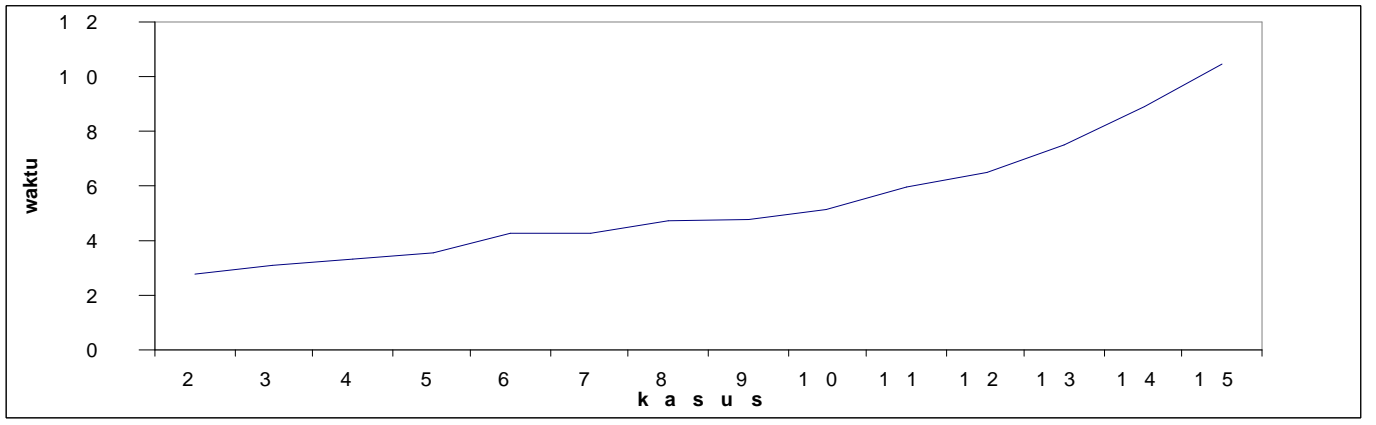

Gambar 5. Grafik pengaruh jumlah depot terhadap waktu proses

Pengaruh jumlah populasi terhadap waktu proses.

Berdasarkan hasil penelitian dan pembahasan gambar 6 di bawah ini menunjukkan bahwa jumlah populasi mempunyai akibat pada waktu proses yang semakin besar. Efek banyaknya populasi terhadap waktu proses adalah berbanding lurus/linier untuk masing-masing uji kasus dengan koefisien korelasi 0.99 .

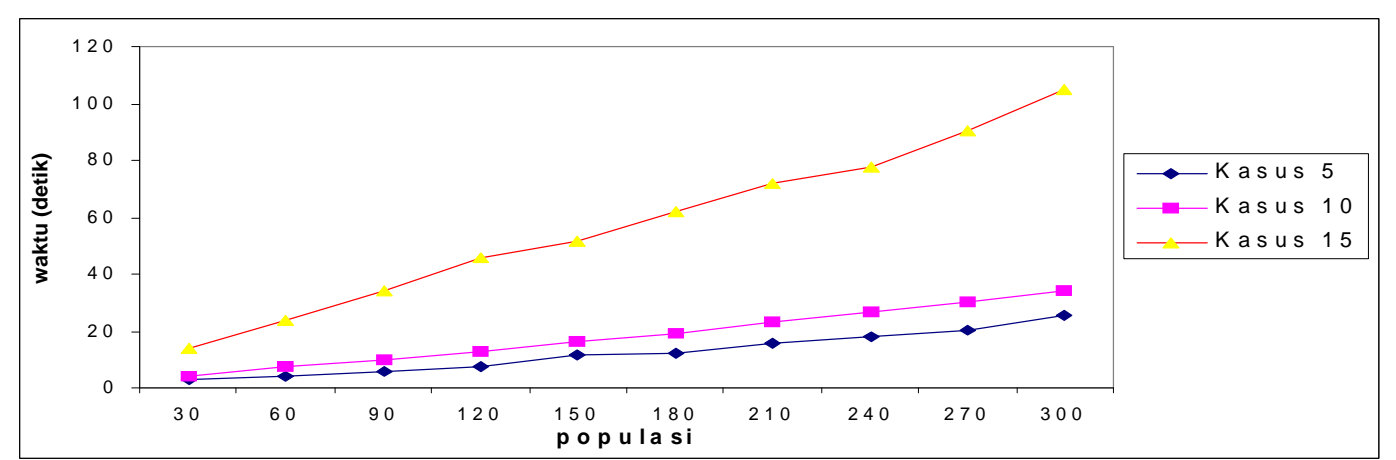

Gambar 6. Grafik populasi terhadap waktu proses

\section{Pengaruh jumlah generasi terhadap waktu proses.}

Gambar 7 menunjukkan bahwa jumlah generasi mempunyai akibat pada waktu proses yang semakin besar. Efek banyaknya generasi terhadap waktu proses adalah berbanding lurus/linier untuk masing-masing uji kasus dengan koefisien korelasi 0.99. Pada gambar 7 ditunjukkan untuk kasus uji 5, 10 dan kasus 15.

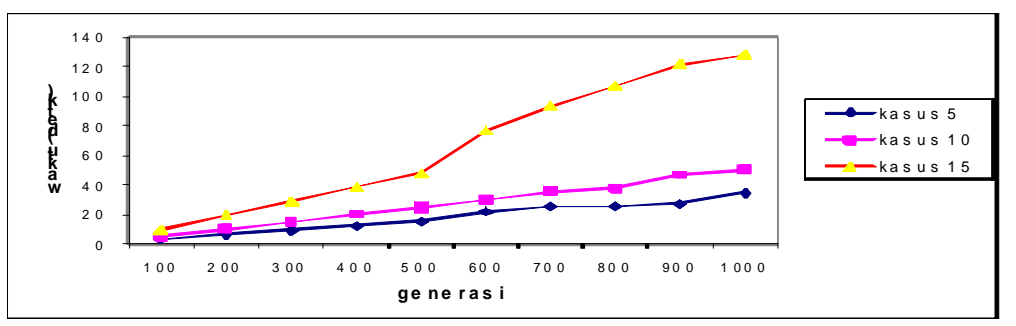

Gambar 7. Grafik generasi terhadap waktu proses

\section{Pengaruh parameter alpha terhadap nilai integral} integral.

Gambar 8 menunjukkan bahwa parameter alpha berpengaruh linier terhadap hasil nilai 


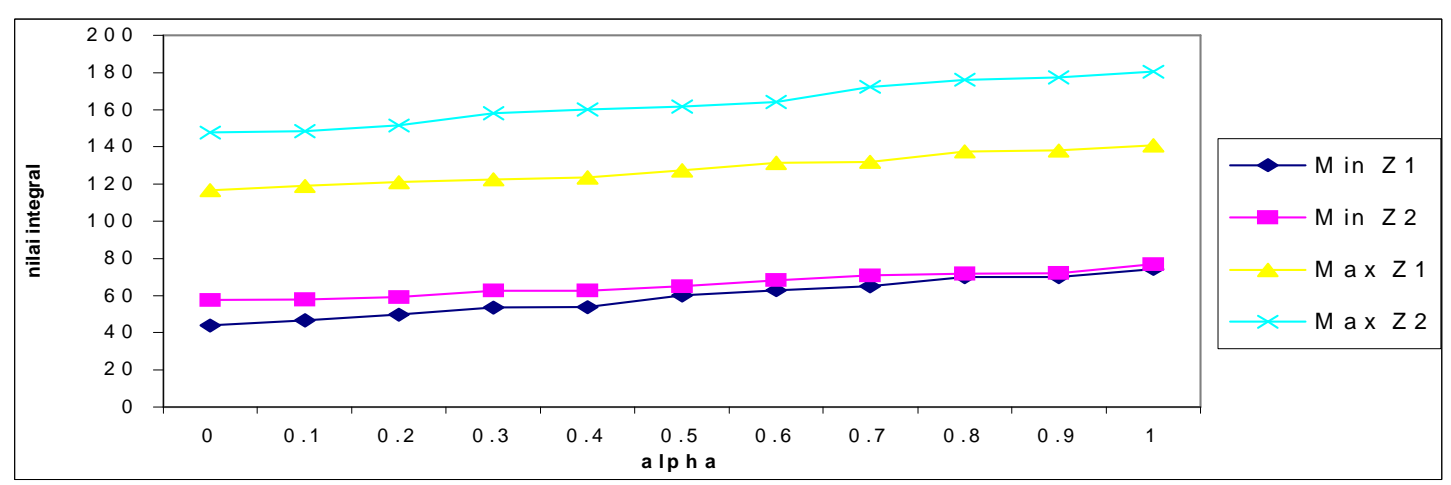

\section{Gambar 8. Grafik parameter alpha terhadap nilai integral untuk uji kasus 5}

\section{Pengaruh generasi terhadap fungsi fitness}

Gambar 9 menunjukkan pengaruh generasi terhadap fungsi fitness. Dari gambar tersebut, terlihat bahwa semakin banyak generasi, maka semakin kecil fungsi fitnessnya, serta konvergen ke suatu nilai tertentu. Pada kasus minimasi ini, semakin kecil nilai fitness yang diperoleh berarti semakin minimal biaya transportasi.

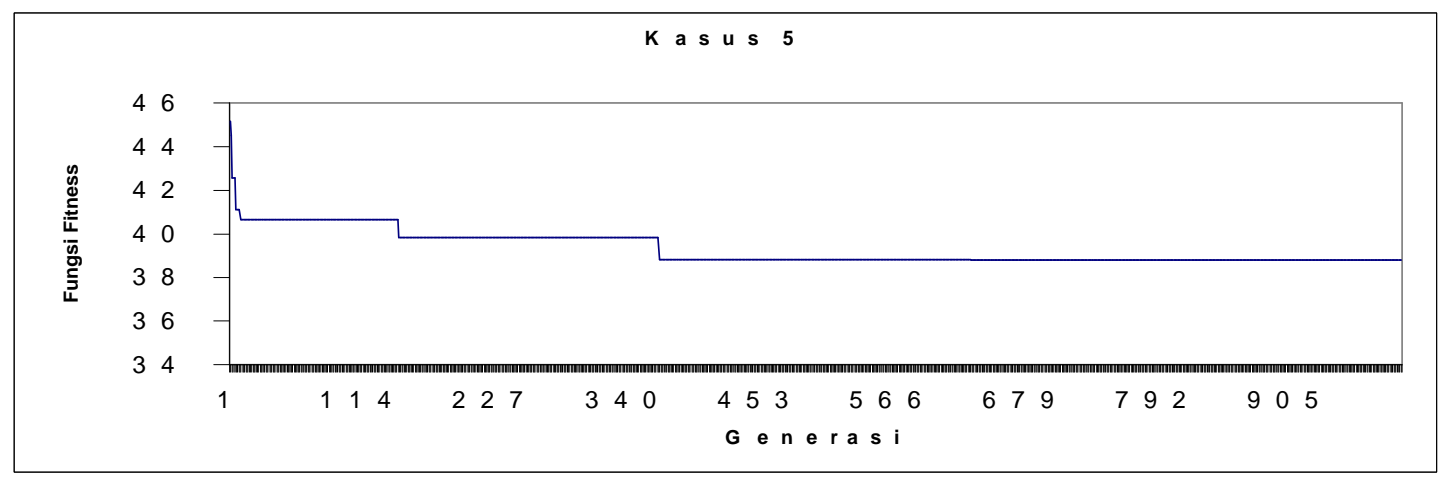

Gambar 9. Grafik generasi terhadap fungsi fitness untuk uji kasus 5

\section{Pengaruh probabilitas crossover terhadap fungsi fitness}

Pada kasus 2 hingga 6 menyebabkan probabilitas crossover stabil dengan nilai fungsi fitness 48.35 yang dapat dilihat pada tabel 6 . Untuk kasus 11 hingga 15, gambar 11 memperlihatkan kecenderungan bahwa pada probabilitas crossover antara 0.2 hingga 0.5 akan meningkatkan nilai fungsi fitness sehingga semakin besar biaya transportasi. Pada kasus 13 dan 15 probabilitas crossover yang mengakibatkan nilai fungsi fitness minimal adalah 0.1.

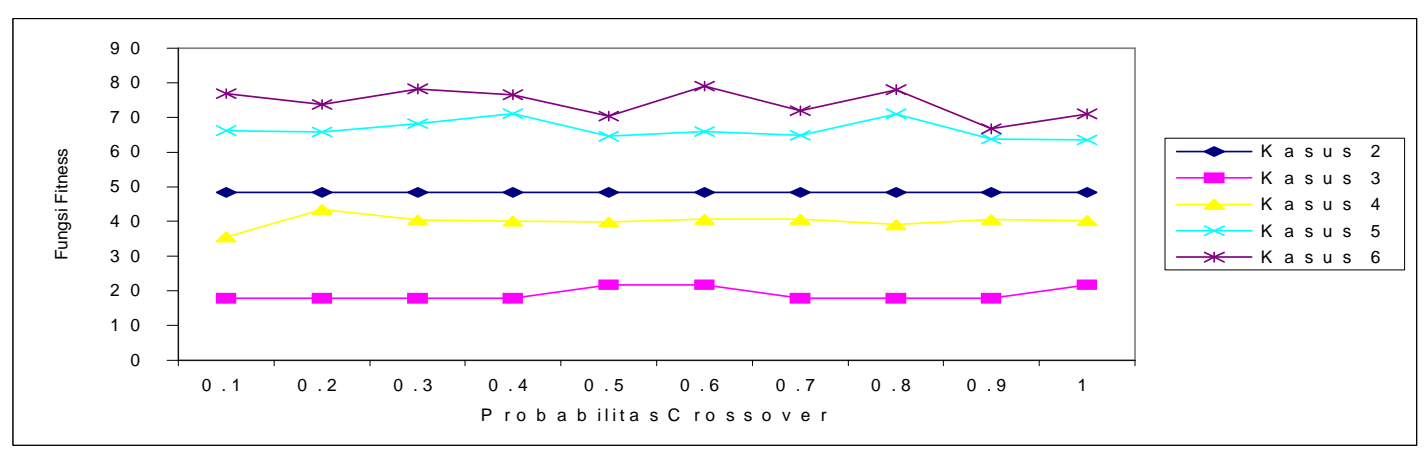

Gambar 10. Grafik pengaruh probabilitas crossover terhadap fungsi fitness 


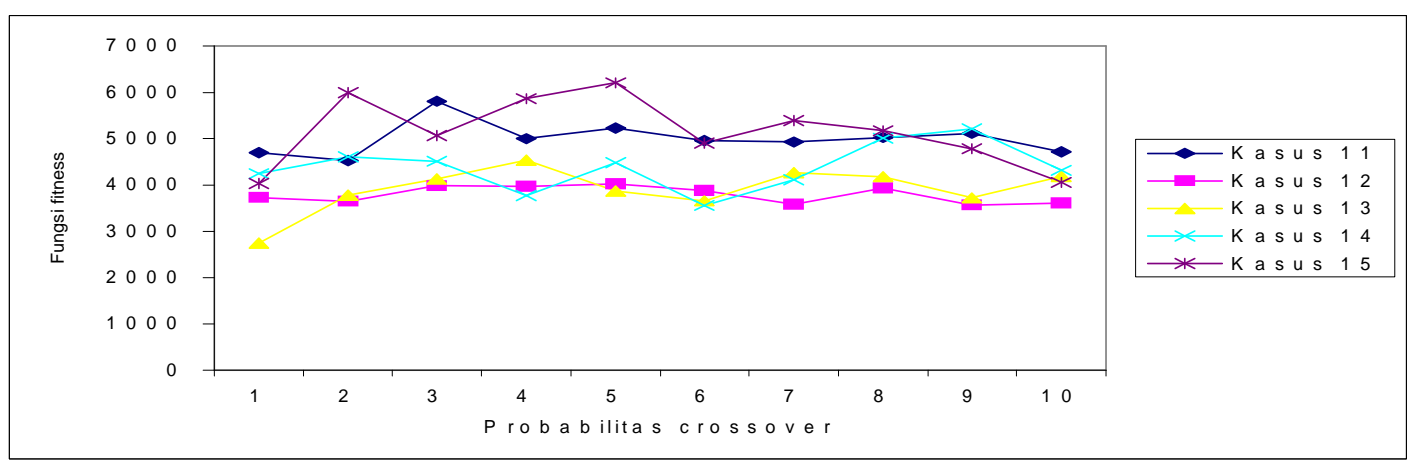

Gambar 11. Grafik pengaruh probabilitas crossover terhadap fungsi fitness

Tabel 6. Probabilitas Crossover terhadap fungsi fitness

\begin{tabular}{|c|c|c|c|c|c|c|c|c|c|c|}
\hline $\begin{array}{l}\text { Crosso } \\
\text { ver }\end{array}$ & \begin{tabular}{|l|} 
Kasus \\
2
\end{tabular} & \begin{tabular}{|l|} 
Kasus \\
3
\end{tabular} & $\begin{array}{l}\text { Kasus } \\
4\end{array}$ & $\begin{array}{l}\text { Kasus } \\
5\end{array}$ & $\begin{array}{l}\text { Kasus } \\
6\end{array}$ & \begin{tabular}{|l|} 
Kasus \\
11
\end{tabular} & \begin{tabular}{|l|} 
Kasus \\
12
\end{tabular} & \begin{tabular}{|l|} 
Kasus \\
13
\end{tabular} & \begin{tabular}{|l|} 
Kasus \\
14
\end{tabular} & $\begin{array}{l}\text { Kasus } \\
15\end{array}$ \\
\hline 0.1 & 48.35 & \begin{tabular}{|l|}
17.8 \\
\end{tabular} & $\begin{array}{r}35.569 \\
67 \\
\end{array}$ & $\begin{array}{r}66.2334 \\
1\end{array}$ & $\begin{array}{r}76.8450 \\
3 \\
\end{array}$ & $\begin{array}{r}4705.77 \\
4 \\
\end{array}$ & 3735.93 & $\begin{array}{r}2744.30 \\
8 \\
\end{array}$ & \begin{tabular}{|r|}
4244.9 \\
82 \\
\end{tabular} & $\begin{array}{r}4033.5 \\
03 \\
\end{array}$ \\
\hline 0.2 & 48.35 & 17.8 & $\begin{array}{r}43.536 \\
54 \\
\end{array}$ & 65.79 & $\begin{array}{r}73.7398 \\
1 \\
\end{array}$ & $\begin{array}{r}4529.42 \\
6 \\
\end{array}$ & $\begin{array}{r}3650.28 \\
4 \\
\end{array}$ & $\begin{array}{r}3777.49 \\
3 \\
\end{array}$ & \begin{tabular}{|r|}
4613.9 \\
85 \\
\end{tabular} & $\begin{array}{r}5994.9 \\
37 \\
\end{array}$ \\
\hline 0.3 & 48.35 & 17.8 & $\begin{array}{r}40.461 \\
78\end{array}$ & $\begin{array}{r}68.1752 \\
8\end{array}$ & $\begin{array}{r}78.2424 \\
2\end{array}$ & 5806.4 & $\begin{array}{r}3988.30 \\
9\end{array}$ & $\begin{array}{r}4129.33 \\
6\end{array}$ & $\begin{array}{r}4510.7 \\
24\end{array}$ & $\begin{array}{r}5071.7 \\
22\end{array}$ \\
\hline 0.4 & 48.35 & 17.8 & $\begin{array}{r}40.129 \\
14\end{array}$ & \begin{tabular}{|r|}
71.0872 \\
5
\end{tabular} & $\begin{array}{r}76.5172 \\
4\end{array}$ & \begin{tabular}{|r|}
5002.32 \\
4
\end{tabular} & \begin{tabular}{|r|}
3970.99 \\
6
\end{tabular} & $\begin{array}{r}4536.13 \\
7\end{array}$ & $\begin{array}{r}3769.5 \\
4\end{array}$ & \begin{tabular}{|r|}
5864.0 \\
12
\end{tabular} \\
\hline 0.5 & 48.35 & 21.7 & $\begin{array}{r}39.875 \\
6\end{array}$ & 64.5902 & 70.3978 & \begin{tabular}{|r|}
5230.32 \\
7
\end{tabular} & \begin{tabular}{|r|}
4027.91 \\
6
\end{tabular} & 3874.4 & $\begin{array}{r}4480.7 \\
46\end{array}$ & $\begin{array}{r}6212.9 \\
2\end{array}$ \\
\hline 0.6 & 48.35 & 21.7 & 40.65 & $\begin{array}{r}65.8929 \\
4\end{array}$ & $\begin{array}{r}79.0147 \\
6\end{array}$ & \begin{tabular}{|r|}
4959.41 \\
2
\end{tabular} & $\begin{array}{r}3882.99 \\
4\end{array}$ & $\begin{array}{r}3659.17 \\
2\end{array}$ & $\begin{array}{r}3560.3 \\
98\end{array}$ & $\begin{array}{r}4908.9 \\
68\end{array}$ \\
\hline 0.7 & 48.35 & 17.8 & 40.65 & $\begin{array}{r}64.8910 \\
1\end{array}$ & $\begin{array}{r}71.9341 \\
2\end{array}$ & \begin{tabular}{|r|}
4927.10 \\
3
\end{tabular} & \begin{tabular}{|r|}
3588.52 \\
7
\end{tabular} & 4272.55 & \begin{tabular}{|r|}
4115.7 \\
5
\end{tabular} & $\begin{array}{r}5398.6 \\
03\end{array}$ \\
\hline 0.8 & 48.35 & 17.8 & $\begin{array}{r}39.082 \\
31\end{array}$ & $\begin{array}{r}71.0417 \\
6\end{array}$ & $\begin{array}{r}77.9836 \\
1\end{array}$ & \begin{tabular}{|r|}
5025.88 \\
3
\end{tabular} & $\begin{array}{r}3937.15 \\
8\end{array}$ & 4184.12 & $\begin{array}{r}5012.2 \\
93\end{array}$ & $\begin{array}{r}5178.0 \\
54\end{array}$ \\
\hline 0.9 & 48.35 & 17.8 & $\begin{array}{r}40.542 \\
48 \\
\end{array}$ & $\begin{array}{r}63.8051 \\
5\end{array}$ & $\begin{array}{r}66.7916 \\
7\end{array}$ & $\begin{array}{r}5115.08 \\
5 \\
\end{array}$ & $\begin{array}{r}573.09 \\
3 \\
\end{array}$ & $\begin{array}{r}3721.55 \\
6 \\
\end{array}$ & \begin{tabular}{|r|}
5216.8 \\
14 \\
\end{tabular} & $\begin{array}{r}4786.6 \\
5 \\
\end{array}$ \\
\hline 1 & 48.35 & 21.7 & $\begin{array}{r}40.283 \\
76 \\
\end{array}$ & $\begin{array}{r}63.4729 \\
2\end{array}$ & 71 & \begin{tabular}{|r|}
4720.58 \\
4 \\
\end{tabular} & 3612.4 & $\begin{array}{r}4186.11 \\
9\end{array}$ & $\begin{array}{r}4315.0 \\
64 \\
\end{array}$ & $\begin{array}{r}4058.5 \\
86 \\
\end{array}$ \\
\hline
\end{tabular}

\section{Pengaruh probabilitas mutasi terhadap fungsi fitness}

Secara umum probabilitas mutasi banyak berpengaruh terhadap fungsi fitnes. Hal ini terlihat pada gambar 12 untuk kasus 2 hingga kasus 6 . Pada kasus 2 mengakibatkan probabilitas mutasi stabil dengan nilai fungsi fitness 48.35 dapat dilihat pada tabel 7 .

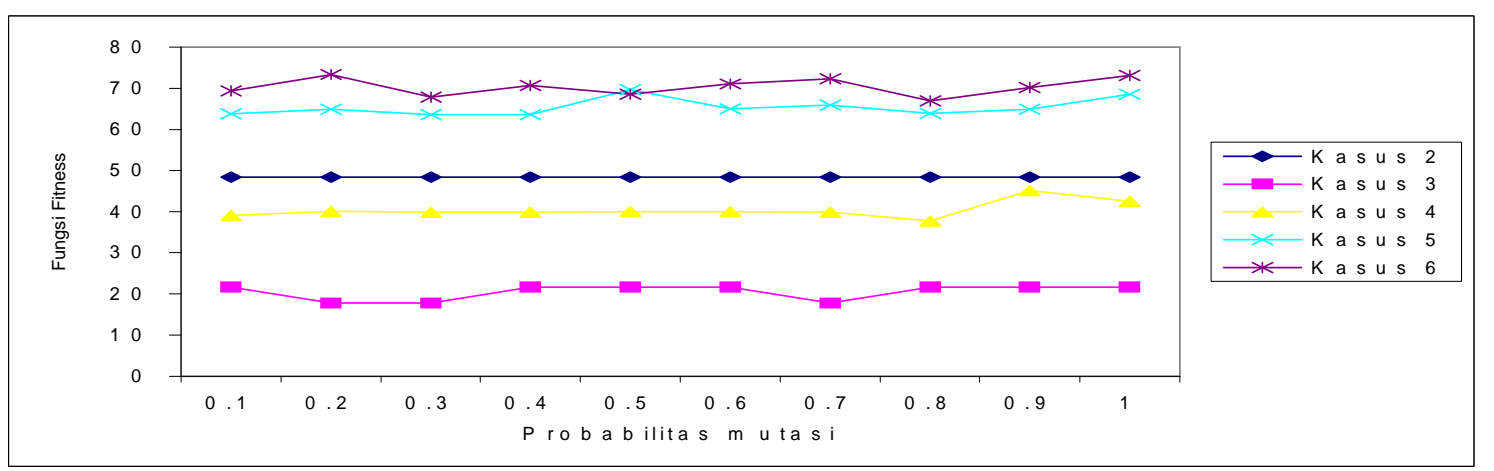

Gambar 12. Grafik pengaruh probabilitas mutasi terhadap fungsi fitness 
Tabel 7. Probabilitas Mutasi terhadap fungsi fitness

\begin{tabular}{|c|c|c|c|c|c|}
\hline Mutasi & Kasus 2 & Kasus 3 & Kasus 4 & Kasus 5 & Kasus 6 \\
\hline 0.1 & 48.35 & 21.7 & 39.13381 & 63.80694 & 69.38125 \\
\hline 0.2 & 48.35 & 17.8 & 40.12914 & 64.88813 & 73.31351 \\
\hline 0.3 & 48.35 & 17.8 & 39.8756 & 63.61012 & 67.87692 \\
\hline 0.4 & 48.35 & 21.7 & 39.8756 & 63.55792 & 70.6475 \\
\hline 0.5 & 48.35 & 21.7 & 40.01169 & 69.65 & 68.49042 \\
\hline 0.6 & 48.35 & 21.7 & 40.07261 & 65.02551 & 70.96765 \\
\hline 0.7 & 48.35 & 17.8 & 39.8756 & 65.88462 & 72.28031 \\
\hline 0.8 & 48.35 & 21.7 & 37.77015 & 63.87446 & 66.95417 \\
\hline 0.9 & 48.35 & 21.7 & 45.1 & 64.84615 & 70.16471 \\
\hline 1 & 48.35 & 21.7 & 42.51111 & 68.46374 & 73.08321 \\
\hline
\end{tabular}

\section{KESIMPULAN}

a. Penyelesaian masalah transportasi BBM Jenis Premium menggunakan Fuzzy di PT.Geotama Energi dapat diselesaikan dengan pendekatan secara heuristik menggunakan algoritma genetika.

b. Waktu proses pada kasus uji akan berbanding lurus dengan hasil kali jumlah depot sumber dan depot tujuan dengan koefisien korelasi 0.89 .

c. Banyaknya populasi adalah berbanding lurus/linier untuk masing-masing kasus uji terhadap waktu proses dengan koefisien korelasi 0.99 .

d. Keluaran dari sistem berupa distribusi transportasi dan biaya minimum total transportasi fuzzy.

\section{DAFTAR PUSTAKA}

Agusnaba, 2009, Belajar Cepat Fuzzy Logic Menggunakan Matlab, Publisher: Andi, ISBN: 9789792909319.

Branke, J., Deb, K., Miettiner, K. \& Slowinski, R., 2008, Multiobjective Optimization Interactive And Evolutionary Approache, Publisher: Springer.

Barnhart, C \& Laporte, G, 2007, Transportation Handbooks In Operation Research And Management Science, Volume 14, Editors Elsevier, Publisher: Springer.

Cascetta, E, 2009, Transportation Systems Analysis Model And Aplication, Second Edition, Publisher : Springer.

Ehrgott, M, 2005, Multikriteria Optimization, Second Edition, Publisher : Springer.

Pranata, A, 2007, Pemrograman Borland Delphi, Andi Offset, Yogyakarta.

Pressman, R.J, 2007, Software Engineering A Practitional Approach, Mc Graw Hill, London.

Sivanandam, S.N \& Deepa, S.N., 2007, Introduction To Genetic Algorithms, Publisher : Springer, ISBN10:354073189X, ISBN13:9783540731894.

Timothy, J,Ross, 2004, Fuzzy Logic With Engineering Applications, Second Edition, Publisher:Wiley,ISBN10:0470860758,ISBN13:9780470860755,

ISBN13:9280470860762. 
Tetsuya, H \& Xin, Y., 2006, The Design Of Innovation : Lesson From And For Competent Genetic Algorithms and Evolutionary Computation, Publisher : Springer. 